\title{
EUFEMISME DAN DISFEMISME PADA MEDIA BERITA DARING REPUBLIKA: PERKEMBANGAN KASUS SETYA NOVANTO EDISI JANUARI 2018
}

\author{
Nanang Heryana \\ Pendidikan Bahasa dan Sastra Indonesia \\ FKIP, Universitas Tanjungpura, Pontianak \\ E-mail: enha.cholil@gmail.com
}

\begin{abstract}
This research aims to identify, describe, and analyze the use of euphemism and dysphemism from the forming process, meaning, and function of Republika online media related to the Development of Setya Novanto Case in January 2018 edition. Method used is descriptive with qualitative approach. Data source is news issued by Republika online regarding Setya Novanto Case Development in January 2018 edition many as 15 news issues. Research data is the use of euphemism and dysphemism including word, phrase, clause, and sentence. Data collecting technique used is documentation and tool of data collecting is news capture. Data analysis method used are identity and distributional method. The meaning of euphemism and dysphemism including collocative meaning and connotative meaning either in form of word, phrase, or clause. Euphemism can function as a protective tool, smoothing utterance, provocation, encouragement, fraud cover, and diplomacy. Dysphemism can function as a negative image of someone or something, showing low value thing, exaggerate something, and showing disrespect.
\end{abstract}

Key Words: Euphism, Dyshemism, Republika Online, Setya Novanto Case

Eufemisme dan disfemisme adalah bentuk perubahan makna dalam bahasa. Selain eufemisme (penghalusan makna) dan disfemisme (pengasaran makna), perubahan makna dapat pula berupa perluasan makna dan penyempitan makna. Perubahan dalam bahasa mungkin terjadi dalam rangka mengakomodasi perkem-bangan sosial, budaya, serta teknologi di masyarakat tuturnya.

Berita sebagai satu di antara penyedia informasi sudah menjadi bagian yang penting dalam kehidupan masyarakat. Informasi seputar masalah ekonomi, sosial, maupun budaya akan selalu menarik perhatian masyarakat di berbagai kalangan. Untuk memenuhi kebutuhan masyarakat akan informasi itulah, berbagai program berita disiarkan melalui stasiun televisi, radio, dan koran. Apalagi, informasi dapat semakin mudah diperoleh melalui media berita daring (online).
Satu di antara media berita daring di Indonesia ialah Republika. Sejak pertengahan 2008 Republika Daring mengalami perubahan besar dari sekadar situs berita sederhana menjadi web portal multimedia. Kemudian, tahun 2009 situs ini mulai melakukan pembenahan isi berita sehingga bukan hanya website yang memindahkan berita koran ke internet. Akan tetapi, mulai memosisikan diri mejadi portal berita yang menampilkan berita-berita setiap saat dan lebih cepat. Hingga sekarang media berita daring ini semakin banyak mengakses berita. Satu di antaranya perkembangan kasus Setya Novanto.

Kasus Setya Novanto berkaitan dengan pengalihan dana e-KTP merupakan satu di antara kasus yang masih hangat dan menjadi berita yang paling ditunggu perkembangannya oleh masyarakat di Indonesia. Perkembangan berita ini tidak hanya dapat diperoleh melalui 
media televisi, surat kabar, atau pun radio. Akan tetapi, masyakat juga dapat mendapatkan perkembangan berita ini melalui media masa daring (online) seperti Republika tersebut.

Dalam penyampaian pesan terhadap pembacanya, berita pastinya meggunakan bahasa yang menarik. Khususnya pada perkembangan kasus Setya Novanto yang hingga sekarang masih menjadi satu di antara berita yang paling ditunggu. Bahkan memasuki Januari 2018 masih terdapat sekita lima belas berita berkaitan dengan kasus tersebut di media daring Republika.

Penulisan berita perkembangan kasus Setya Novanto masih menjadi berita hangat di media daring seperti Republika. Khusunya edisi Januari 2018 ditemukan hal menarik, yaitu istilah eufemisme dan disfemisme dalam pemaparan berita tersebut. Penggunaan istilah ini sangat menarik ditinjau dari segi proses pembentukan, fungsi penggunaanannya, serta maknanya. Eufemisme dan disfemisme dapat berupa kata, frasa, dan kalimat. Misalnya pada kata korupsi mengarah pada pengasaran makna (disfemisme). Sebaliknya frasa penyalahgunaan anggaran merupakan eufemisme.

Berikut ini dirumuskan beberapa masalah dalam penelitian ini, yaitu 1) Bagaimanakah proses pembentukan eufemisme dan disfemisme pada media berita daring Republika Perkembangan Kasus Setya Novanto edisi Januari 2018?, 2) Bagaimanakah makna eufemisme dan disfemisme pada media berita daring Republika Perkembangan Kasus Setya Novanto edisi Januari 2018?, dan 3) Bagaimanakah fungsi eufemisme dan disfemisme pada media berita daring Republika Perkembangan Kasus Setya Novanto edisi Januari 2018?

Penelitian ini bertujuan untuk mengidentifikasi, mengklasifikasikan, mendeskripsikan, dan menganalisis penggunaan eufemisme dan disfemisme media berita daring Republika Perkem-bangan Kasus Setya Novanto edisi Januari 2018. Pertama, berkaitan dengan proses pembentukan eufemisme dan disfemisme dalam media berita daring. Kedua, makna eufemisme dan disfemisme dalam media berita daring. Ketiga, fungsi penggunaan eufemisme dan disfemisme dalam media berita daring.
Penelitian ini menggunakan sumber pustaka acuan primer yang relevan dan terkini dengan mengutamakan hasil penelitian pada jurnal ilmiah. Berikut ini beberapa jurnal yang berhubungan dengan penelitian. Pertama, hasil penelitian yang dilakukan oleh Amelia Yuli Astuti berjudul Eufemisme Bahasa Pendukung Capres RI Tahun 2014 dalam Akun Facebook: Kajian Sosiopragmatik. Hasil analisis penelitian terhadap penggunaan eufemisme menunjukkan bahwa penggu-naan eufemisme oleh para pendukung calon presiden RI tahun 2014 terdiri atas proses pembentukan eufemisme berupa kata dan frasa. Kedua, penelitian Penelitian tentang eufemisme juga dilakukan oleh Ana (2014) yang mengkaji penggunaan eufemisme dalam surat kabar harian Singgalang. Tujuan kajian ini adalah untuk mengetahui makna dan fungsi penggunaan eufemisme dalam surat kabar.

Chaer (2009:144) mengatakan bahwa eufemisme adalah gejala ditampil-kannya katakata atau bentuk-bentuk yang dianggap memiliki makna yang lebih halus atau lebih sopan daripada yang akan digantikan. Menurut Djajasudarma (1993: 78), eufemisme termasuk ke dalam pergeseran makna. Pergeseran makna dapat terjadi pada kata, frasa, bahkan kalimat. Pergeseran makna dapat terjadi dengan menggantikan simbol baik berupa kata, frasa, maupun kalimat dengan yang baru dan maknanya akan bergeser. Warren (1992) menyatakan bahwa bentuk eufemisme melibatkan sebuah proses pembentukan dan membagi menjadi tiga bentuk inovasi formal, yaitu pembentukan kata, modifikasi fonem, dan kata pinjaman.

Menurut Leech (1981), makna eufemisme juga dapat diketahui berdasar-kan akibat asosiasi makna yang diketahui makna aslinya. Asosiasi makna terjadi karena adanya hubungan antara makna konseptual dan makna asosiatif. Untuk mengetahui pembagian dari makna konseptual dan makna asosiatif tersebut, maka dapat dilihat dari tabel berikut yang dipaparkan oleh Leech (1981:9-23) tentang pembagian makna. Makna asosiatif adalah makna kata yang berkenaan dengan adanya hubungan kata itu sendiri dengan sesuatu yang berada di luar bahasa (Leech, 1981:18). Berdasarkan tipe-tipe makna yang 
dipaparkan oleh Leech di atas, dapat disimpulkan bahwa makna yang dikategorikan sebagai makna asosiatif adalah makna konotatif, makna sosial, makna afektif, makna refleksi, dan makna kolokatif.

Eufemisme digunakan dalam ranah kehidupan sosial, politik, agama, dan budaya. Beberapa ahli linguistik telah mengklasifikasikan fungsi dari eufemisme berdasarkan fenomena kebahasaan. Menurut Wardaugh (1986:229), penggu-naan eufemisme bermaksud jika suatu kata yang tidak dapat dinyatakan, maka pengguna bahasa akan menggantinya dengan cara lain. Secara umum fungsi eufemisme adalah untuk menjadikan sebuah makna yang pada awalnya bersifat kasar atau tabu menjadi makna yang lebih halus. Burridge (2012) membagi fungsi eufemisme menjadi enam hal, yaitu eufemisme perlindungan (the protective eufemisme), eufemisme kecurangan (the underhand euphemism), eufemisme penyemangat (the uplifting euphemism), eufemisme profokasi (the provocative euphemism), kepaduan eufemisme (the cohesive euphemism), dan eufemisme menggelikan (the ludic euphemism). Senada dengan hal tersbut, Wijana (2008) membagi lima fungsi utama eufemisme di dalam berbahasa, di antaranya alat menghaluskan ucapan, alat merahasiakan sesuatu, alat berdiplomasi, alat pendidikan, dan alat penolak bala.

Allan dan Burridge (dalam Alvestad, 2014:162) mendefinisikan disfemisme dengan jelas sebagai berikut:

(Dysphemism is) an expression with connotations that are offensive either about the denotatum or to the audience, or both, and it is substituted for a neutral or euphemistic expression for just that reason.

Allan dan Burridge, dalam pernyataan mereka diatas, tidak dapat memisahkan disfemisme dari eufemisme dan ungkapan netral (ortofemisme). Mereka mengungkapkan bahwa disfemisme adalah ungkapan yang berkonotasi kasar tentang suatu hal atau tentang seseorang, atau juga keduanya, dan merupakan substitusi untuk ungkapan netral (ortofemisme) dan ungkapan eufemisme karena alasan tertentu. Konotasi ini sendiri didefinisikan Allan dan Burridge sebagai efek semantik (nuansa makna) yang timbul karena adanya pengetahuan ensiklopedik tentang makna denotasi kata serta pengalaman, kepercayaan dan konteks digunakannya ungkapan itu. Dengan kata lain, disfemisme dipilih penutur untuk menunjukkan penilaian negatifnya mengenai sesuatu atau seseorang serta menimbulkan nuansa negatif melalui bahasa yang digunakannya.

Pendapat Allan dan Burridge mengenai disfemisme ini sejalan dengan pendapat McArthur (dalam Duda, 2010: 10) yang mendefinisikan disfemisme sebagai "the use of a negative or disparaging expression to describe something or someone". Menurut McArthur, disfemisme adalah penggunaan ungkapan negatif atau ungkapan berisi kritik untuk mendeskripsikan sesuatu atau seseorang. Dengan menggunakan ekspresi disfemisme, penutur memiliki intensi untuk melukai perasaan pendengarnya dengan pengungkapan suatu realitas secara langsung.

Menurut Zolner (dalam Kurniawati, 2009), disfemisme digunakan dengan berbagai latar belakang seperti, menyatakan hal yang tabu, tidak senonoh, asusila, menunjukkan rasa tidak suka atau tidak setuju terhadap seseorang atau sesuatu, penggambaran yang negatif tentang seseorang, mengungkapkan kemarahan atau kejengkelan, mengumpat atau memaki, menunjukkan rasa tidak hormat atau merendahkan seseorang, mengolok-olok, mencela, atau menghina, melebih-lebihkan sesuatu, menghujat atau mengkritik, dan menunjukkan sesuatu hal yang bernilai rendah.

\section{METODE}

Metode yang digunakan dalam penelitian ini adalah metode deskriptif. Bentuk penelitian yang digunakan dalam penelitian ini adalah bentuk kualitatif. Penelitian kualitatif merupakan suatu pendekatan dalam melakukan penelitian yang berorientasi pada fenomena atau gejala yang bersifat alami (Mahmud, 2011: 89). Menurut Satori dan Komariah (2011: 25) penelitian kualitatif adalah suatu bentuk penelitian yang mengungkapkan situasi sosial tertentu dengan mendeskripsikan kenyataan secara benar, dibentuk oleh kata-kata berdasarkan teknik pengumpulan dan analisis 
data yang relevan yang diperoleh dari situasi yang alamiah.

Sumber data penelitian ini berupa berita pada media daring Republika Perkembangan Kasus Setya Novanto edisi Januari 2018. Data penelitian ini adalah penggunaan eufemisme dan disfemisme berupa kata, frasa, dan kalimat.

Teknik yang dipergunakan dalam penelitian ini adalah teknik pengumpulan data dengan dokumentasi dan alat pengumpul data dokumen berupa berita pada media daring Republika edisi Januari 2018. Hasil dokumentasi digunakan sebagai pengamatan dan pencatatan secara sistematis terhadap gejala yang tampak pada penelitian. Teknik dokumentasi ini dipergunakan untuk mengidentifikasi penggunaan produksi ujaran dalam diskusi panel tersebut.

Peneliti menyimak dan mengamati fenomena eufemisme dan disfemisme pada kolom berita daring Republika edisi Januari 2018. Teknik yang digunakan dalam penelitian ini adalah teknik simak bebas libat cakap atau teknik SBLC. Selain teknik SBLC, peneliti juga menggunakan teknik capture. Peneliti mengumpulkan data dengan menangkap (capture) dokumen yang memiliki bentuk eufemisme dan disfemisme pada media berita daring tersebut. Dalam mengumpul-kan data, peneliti mencari bentuk eufemisme dan disfemisme dengan mengaitkannya ke dalam bentuk makna terhadap masing- masing data yang telah dikumpulkan. Selanjutnya data tersebut disusun ke dalam sebuah tabel. Tabel bertujuan untuk menyusun bentuk eufemisme dan disfemisme berdasarkan kriteria masingmasing penggunaan bahasa.

Ada dua metode analisis data yang digunakan dalam penelitian ini, yaitu metode padan dan metode agih (Sudaryanto, 2015). Metode padan adalah alat penentunya di luar, terlepas, dan tidak menjadi bagian dari bahasa yang bersangkutan. Metode padan yang dipakai adalah metode padan referensial, metode translasional, metode ortografis, dan metode pragmatis. Alat penentu metode padan referensial adalah daya pilah yang digunakan sebagai pembeda referen (sosok yang ditunjukkan oleh kata tersebut). Metode padan yang dipakai dalam penelitian ini adalah dengan cara melihat fitur-fitur makna.

Penyajian hasil analisis data dapat menggunakan penyajian informal dan formal. Akan tetapi, dalam penelitian ini hanya digunakan penyajian informal. Metode informal digunakan pada pemaparan hasil analisis data berupa kata-kata atau uraian tanpa lambanglambang formal yang bersifat teknis.

\section{HASIL DAN PEMBAHASAN}

Penelitian ini sudah memasuki proses pengumpulan data berupa pendokumentasian berita daring Republika berjumlah 15 berita edisi Januari 2018. Setelah itu, menandai bagianbagian teks yang menggunakan eufemisme dan disfemisme. Bagian-bagian teks yang menggunakan eufemisme dan disfemisme diinventarisasikan dengan pengcodingan.

Tabel 1

Contoh Data Eufemisme dalam Media Berita Daring Republika Perkembangan Kasus Setya Novanto Edisi Januari 2018

\begin{tabular}{llll}
\hline NO & $\begin{array}{l}\text { KATA/ } \\
\text { FRASA }\end{array}$ & $\begin{array}{c}\text { BERI- } \\
\text { TA }\end{array}$ & $\begin{array}{c}\text { BAGI- } \\
\text { AN }\end{array}$ \\
\hline 3 & $\begin{array}{l}\text { Kerugian } \\
\text { keuangan } \\
\text { Negara }\end{array}$ & B1 & P8 K1 \\
\hline 4 & $\begin{array}{l}\text { Menyalah } \\
\text {-gunakan } \\
\text { kewenang } \\
\text {-an }\end{array}$ & B1 & P14 K1 \\
\hline 15 & Ketum & B6 & P6 K4 \\
\hline 16 & $\begin{array}{l}\text { Pembagia } \\
\text { nfee }\end{array}$ & B6 & P6 K4 \\
\hline 31 & $\begin{array}{l}\text { Melepas } \\
\text { jabatan- } \\
\text { nya }\end{array}$ & B9 & P5 K3 \\
\hline
\end{tabular}

Berdasarkan uraian tabel data tersebut terdapat $49 \mathrm{kata} /$ frasa yang termasuk dalam eufemisme dari 15 berita daring Republika Perkembangan Kasus Setya Novanto edisi Januari 2018. Inventaisasi data eufemisme disusun berdasarkan kata/frasa, berita (pada berita ke berapa), dan bagian (paragraph dan kalimat). Inventarisasi data disertai coding ini untuk 
mempermudah peneliti dalam mendata kata atau pun frasa yang termasuk eufemisme.

Tabel 2

Contoh Data Disfemisme dalam Media Berita Daring Republika Perkembangan Kasus Setya Novanto Edisi Januari 2018

\begin{tabular}{|c|c|c|c|}
\hline NO & $\begin{array}{l}\text { KATA/ } \\
\text { FRASA }\end{array}$ & $\begin{array}{c}\text { BERI- } \\
\text { TA }\end{array}$ & $\begin{array}{l}\text { BAGI- } \\
\text { AN }\end{array}$ \\
\hline 1 & $\begin{array}{l}\text { Tersang } \\
\text {-ka }\end{array}$ & $\begin{array}{l}\text { B1, } \\
\text { B5, } \\
\text { B5, } \\
\text { B12 }\end{array}$ & $\begin{array}{ll}\mathrm{P} 1 & \mathrm{~K} 1, \\
\mathrm{P} 1 & \mathrm{~K} 2, \\
\mathrm{P} 2 & \mathrm{~K} 1, \\
\mathrm{P} 2 & \mathrm{~K} 1\end{array}$ \\
\hline 2 & Korupsi & $\begin{array}{l}\text { B1, } \\
\text { B3, } \\
\text { B4, } \\
\text { B5, } \\
\text { B5, } \\
\text { B6, B7 }\end{array}$ & $\begin{array}{ll}\text { P1 } & \mathrm{K} 1, \\
\mathrm{P} 2 & \mathrm{~K} 2, \\
\mathrm{P} 1 & \mathrm{~K} 1, \\
\mathrm{P} 2 & \mathrm{~K} 1, \\
\mathrm{P} 3 & \mathrm{~K} 1, \\
\mathrm{P} 3 & \mathrm{~K} 1, \\
\mathrm{P} 1 & \mathrm{~K} 1\end{array}$ \\
\hline 5 & Cabut & B5 & J5 \\
\hline 11 & Lari & B9 & P2 K1 \\
\hline 12 & $\begin{array}{l}\text { Kehi- } \\
\text { langan } \\
\text { nyali }\end{array}$ & B10 & $\begin{array}{l}\text { P1 K1, } \\
\text { P5 K1 }\end{array}$ \\
\hline
\end{tabular}

Berdasarkan uraian tabel data tersebut terdapat $20 \mathrm{kata} /$ frasa yang termasuk dalam disfemisme dari 15 berita daring Republika Perkembangan Kasus Setya Novanto edisi Januari 2018. Inventaisasi data disfemisme disusun berdasarkan kata/frasa, berita (pada berita ke berapa), dan bagian (paragraf dan kalimat). Inventarisasi data disertai coding ini untuk mempermudah peneliti dalam mendata kata atau pun frasa yang termasuk disfemisme.

\section{Bentuk Eufemisme dan Disfemisme Media Berita Daring Kasus Setya Novanto Edisi Januari 2018}

Bagian ini disajikan analisis bentuk eufemisme dan disfemisme pada media berita daring Republika Kasus Setya Novanto Edisi Januari 2018. Data-data yang telah diambil dari media berita daring tersebut telah diinventarisasi dalam bentuk tabel. Selanjutnya, analisis bentuk eufemisme dan bentuk disfemisme dipaparkan sebagai berikut.
1.1 Bentuk Eufemisme Media Berita Daring Kasus Setya Novanto Edisi Januari 2018

Berdasarkan uraian tabel data tersebut terdapat $49 \mathrm{kata} /$ frasa yang termasuk dalam eufemisme dari 15 berita daring Republika Perkembangan Kasus Setya Novanto edisi Januari. Analisis bentuk eufemisme menggunakan teori Warren (1992) tiga bentuk inovasi formal, yaitu pembentukan kata, modifikasi fonem, dan kata pinjaman.

\section{TDE 3}

Kerugian keuangan negara

Penggunaan frasa kerugian keuangan Negara terdapat pada penggalan berita berikut ini.

(1a) Keberatan tersebut antara lain mengenai kerugian keuangan negara tidak nyata dan tidak pasti karena dalam surat dakwaan Irman dan Sugiharto serta Andi Agustinus, kerugian negara adalah senilai Rp2,31 triliun berdasarkan perhitungan Badan Pengawasan Keuangan dan Pembangunan (BPKP) itu tidak memperhitungkan penerimaan 7,3 juta dolar AS atau setara Rp94,9 miliar untuk Setya Novanto, 800 ribu dolar AS atau setara Rp10,4 miliar untuk Charles Sutanto dan Rp2 juta untuk Tri Sampurno yang seluruhnya sebesar Rp105,3 miliar. (B1, P8K1)

(1b) Keberatan tersebut antara lain mengenai korupsi uang negara tidak nyata dan tidak pasti karena dalam surat dakwaan Irman dan Sugiharto serta Andi Agustinus, kerugian negara adalah senilai Rp2,31 triliun berdasarkan perhitungan Badan Pengawasan Keuangan dan Pembangunan (BPKP) itu tidak memperhitungkan penerimaan 7,3 juta dolar AS atau setara Rp94,9 miliar untuk Setya Novanto, 800 ribu dolar AS atau setara Rp10,4 miliar untuk Charles Sutanto dan Rp2 juta untuk Tri Sampurno yang seluruhnya sebesar Rp105,3 miliar.

Berdasarkan penggalan kalimat $1 \mathrm{a}$ dan $1 \mathrm{~b}$ tersebut penggunaan eufemisme, yaitu frasa kerugian keuangan negara. Secara bentuk, frasa kerugian keuangan negara merupakan bentuk eufemisme dengan melalui proses pembentukan kata, yaitu penggabungan kata (compounding). Proses ini menggabungkan dua kata yang memiliki makna yang lebih halus untuk menggantikan istilah yang yang kurang dapat diterima. Frasa kerugian keuangan negara 
merujuk kepada korupsi berkaitan dengan uang negara. Dalam hal surat dakwaan Irman dan Sugiharto serta Andi Agustinus.

\section{TDE 4}

Menyalahgunakan kewenangan

(1a) Pasal tersebut mengatur tentang orang yang melanggar hukum, menyalahguna-kan kewenangan, kesempatan atau sarana yang ada padanya jabatan atau kedudukan sehingga dapat merugikan keuangan dan perekonomian negara dan memperkaya diri sendiri, orang lain atau korporasi dengan ancaman pidana penjara maksimal 20 tahun dan denda paling banyak Rp1 miliar. (B1, P12K1)

(1b) Pasal tersebut mengatur tentang orang yang melanggar hukum, korupsi kekuasaan, kesempatan atau sarana yang ada padanya jabatan atau kedudukan sehingga dapat merugikan keuangan dan perekonomian negara dan memperkaya diri sendiri, orang lain atau korporasi dengan ancaman pidana penjara maksimal 20 tahun dan denda paling banyak Rp1 miliar

Penggunaan eufemisme, yaitu frasa menyalahgunakan kewewenangan. Secara bentuk, frasa menyalahgunakan kewewenangan merupakan bentuk eufemisme dengan melalui proses pembentukan kata, yaitu penggabungan kata (compounding). Proses ini menggabungkan dua kata yang memiliki makna yang lebih halus untuk menggantikan istilah yang yang kurang dapat diterima. Frasa menyalahgunakan wewenang merujuk kepada korupsi kekuasaan atau jabatan. Dalam hal ini pasal yang mengatur hal tersebut dan ancaman bagi yang melakukannnya.

\subsection{Bentuk Disfemisme Media Berita Daring Kasus Setya Novanto Edisi Januari 2018}

Berdasarkan uraian tabel data tersebut terdapat $32 \mathrm{kata} /$ frasa yang termasuk dalam eufemisme dari 15 berita daring Republika Perkembangan Kasus Setya Novanto edisi Januari. Analisis bentuk eufemisme menggunakan teori Warren (1992) tiga bentuk inovasi formal, yaitu pembentukan kata, modifikasi fonem, dan kata pinjaman.

\section{TDD 2}

Korupsi (1a) Terdakwa kasus korupsi KTP Elektronik Setya Novanto menjalani sidang lanjutan di Pengadilan Tipikor, Jakarta Pusat, Kamis (11/1). (B4, P1K1)

(1b) Terdakwa kasus penyalahgunaan uang negara KTP Elektronik Setya Novanto menjalani sidang lanjutan di Pengadilan Tipikor, Jakarta Pusat, Kamis (11/1).

Berdasarkan penggalan kalimat tersebut penggunaan disfemisme yaitu kata korupsi. Secara bentuk, kata korupsi merupakan bentuk disfemisme dengan melalui proses inovasi semantis, yaitu bentuk implikasi. Kata korupsi merujuk arti penyalahgunaan uang negara pada kalimat (1b), ((2b), (3b), dan (4b). Dalam hal ini, korupsi KTP elektronik yang dilakukan Setya Novanto terlihat pada (1a), (2a), (3a), dan (4a)

\section{TDD 5}

\section{Cabut}

(1a) Menkes Bisa Cabut Izin RS yang Rawat Setya Novanto. (B5, J5)

(1b) Menkes Bisa Mengambil Hak Izin RS yang Rawat Setya Novanto.

Berdasarkan penggalan kalimat tersebut penggunaan disfemisme yaitu kata cabut. Secara bentuk, kata cabut merupakan bentuk disfemisme dengan melalui proses inovasi semantis, yaitu bentuk implikasi. Kata cabut secara tidak langsung merujuk pada arti mengambil hak terlihat kalimat (1b) dan (2b). Dalam hal ini, Menkes Bisa Cabut Izin RS yang Rawat Setya Novanto.

\section{Makna Eufemisme dan Disfemisme Media Berita Daring Kasus Setya Novanto Edisi Januari 2018}

Bagian ini disajikan analisis makna eufemisme dan disfemisme pada media berita daring Republika Kasus Setya Novanto Edisi Januari 2018. Data-data yang telah diambil dari media berita daring tersebut telah diinventarisasi dalam bentuk tabel. Selanjutnya, analisis makna eufemisme dan bentuk disfemisme dipaparkan sebagai berikut.

\subsection{Makna Eufemisme Media Berita Daring Kasus Setya Novanto Edisi Januari 2018}


Berdasarkan uraian tabel data tersebut terdapat $49 \mathrm{kata} / \mathrm{frasa}$ yang termasuk dalam eufemisme dari 15 berita daring Republika Perkembangan Kasus Setya Novanto edisi Januari. Analisis makna eufemisme menggunakan teori Leech (1981), makna eufemisme juga dapat diketahui berdasarkan akibat asosiasi makna yang diketahui makna aslinya. Asosiasi makna terjadi karena adanya hubungan antara makna konseptual dan makna asosiatif. Untuk mengetahui pembagian dari makna konseptual dan makna asosiatif tersebut asosiatif adalah makna konotatif, makna sosial, makna afektif, makna refleksi, dan makna kolokatif.

\subsubsection{Makna Kolokatif}

Makna kolokatif lebih berhubungan dengan penempatan makan dalam frasa sebuah bahasa. Makna kolokatif adalah makan kata yang ditentukan oleh openggunaannya dalam kalimat. Kata tang bermakna kolokatif memiliki makna yang sebenarnya. Dalam hal ini, makna eufemisme pada Media Berita Daring Kasus Setya Novanto Edisi Januari 2018 yang tergolong makna kolokatif. Berikut ini dipaparkan analisis makna kolokatif tersebut.

\section{TDE 30}

Kontradiksi

"Dan di sini ada kontradiksi dengan politisi. (B9, P4K1)

Penggalan kalimat tersebut menunjukkan penggunaan eufemisme pada kata kontradiksi. Kontradiksi berarti adanya pertentangan. Dalam hal ini pernyataan tersebut, terdapat kontradiksi dengan politisi. Kata kontradiksi memiliki hubungan makna kolokatif.

Analisis komponensial makna pada kata kontradiksi dan pertentangan sebagai berikut.

\begin{tabular}{|l|c|c|}
\hline & $\begin{array}{c}\text { Kontra- } \\
\text { diksi }\end{array}$ & $\begin{array}{c}\text { Perten- } \\
\text { tangan }\end{array}$ \\
\hline Dua hal & + & + \\
\hline $\begin{array}{l}\text { Bertolak } \\
\text { belakang }\end{array}$ & + & + \\
\hline Perselisihan & - & + \\
\hline Pertikaian & - & + \\
\hline
\end{tabular}

Pengunaan kata kontradiksi dalam konteks kalimat tersebut untuk merujuk makna adanya pertentangan. Kata kontradiksi merupakan eufemisme yang digunakan untuk mengubah makna negatif agar terkesan menjadi lebih halus karena merujuk pada sesuatu, yaitu adanya suatu pertentangan dengan politisi.

\subsubsection{Makna Konotatif}

\section{TDE 16}

\section{Pembagian fee}

"Ihwal jumlah jatah yang diterima mantan ketum Partai Golkar itu masih menjadi yang terbesar dalam pembagian fee megaproyek itu, menurut Firman, masih harus dibuktikan".(B6, P6K5)

Penggalan kalimat tersebut menunjukkan penggunaan eufemisme pada frasa pembagian fee. Frasa pembagian fee memiliki hubungan makna konotasi. Penggunaan frasa pembagian fee untuk merujuk makna pembagian biaya atau duit. Secara tidak langsung frasa pembagian duit ini memberikan efek yang terkesan negatif sekaligus menyindir mantan ketum Partai Golkar itu diduga masih menjadi yang terbesar dalam pembagian fee megaproyek itu. Oleh karena itu, digunakan kata yang lebih halus, yaitu pembagian fee. Dalam hal ini, Firman mengemukakan bahwa perlu pembuktian Ihwal jumlah jatah yang diterima mantan ketum Partai Golkar itu masih menjadi yang terbesar dalam pembagian fee megaproyek itu.

\subsection{Makna Disfemisme Media Berita Daring Kasus Setya Novanto Edisi Januari 2018}

Berdasarkan uraian tabel data tersebut terdapat 20 kata atau frasa yang termasuk dalam disfemisme dari 15 berita daring Republika Perkembangan Kasus Setya Novanto edisi Januari 2018. Analisis makna disfemisme menggunakan teori Leech (1981), makna eufemisme juga dapat diketahui berdasarkan akibat asosiasi makna yang diketahui makna aslinya. Asosiasi makna terjadi karena adanya hubungan antara makna konseptual dan makna asosiatif. Untuk mengetahui pembagian dari makna konseptual dan makna asosiatif tersebut asosiatif adalah makna konotatif, makna sosial, makna afektif, makna refleksi, dan makna kolokatif.

\subsubsection{Makna Kolokatif}

Makna kolokatif lebih berhubungan dengan penempatan makan dalam frasa sebuah 
bahasa. Makna kolokatif adalah makan kata yang ditentukan oleh openggunaannya dalam kalimat. Kata tang bermakna kolokatif memiliki makna yang sebenarnya. Dalam hal ini, makna disfemisme pada Media Berita Daring Kasus Setya Novanto Edisi Januari 2018 yang tergolong makna kolokatif. Berikut ini dipaparkan analisis makna kolokatif tersebut.

\section{TDD 7}

\section{Membongkar}

"Status tersebut jika dikabulkan Komisi Pemberantasan Korupsi (KPK), disebut bakal membongkar nama-nama besar lain terkait korupsi KTP-el”. (B6, P1K1).

Berdasarkan penggalan kalimat tersebut penggunaan disfemisme yaitu kata membongkar. Kata membongkar berarti membuka rahasia. Dalam hal ini, Status tersebut jika dikabulkan Komisi Pemberantasan Korupsi (KPK), disebut bakal membongkar nama-nama besar lain terkait korupsi KTP-el. Kata membongkar memiliki hubungan makna kolokatif.

Analisis komponensial makna pada kata membongkar dan membuka sebagai berikut.

\begin{tabular}{|l|c|c|}
\hline & $\begin{array}{c}\text { Membong } \\
\text {-kar }\end{array}$ & $\begin{array}{c}\text { Membu- } \\
\text { ka }\end{array}$ \\
\hline Merusak & + & - \\
\hline Merobohkan & + & - \\
\hline Paksa & + & - \\
\hline Menguraikan & + & + \\
\hline $\begin{array}{l}\text { Mengungkap } \\
\text { kan }\end{array}$ & + & + \\
\hline
\end{tabular}

Pengunaan kata membongkar dalam konteks kalimat tersebut untuk merujuk makna membuka rahasia. Kata membongkar merupakan disfemisme yang digunakan untuk mengubah makna yang lebih halus menjadi makna yang terkesan negatif dengan tujuan tertentu. Hal ini merujuk pada Status tersebut jika dikabulkan Komisi Pemberantasan Korupsi (KPK), disebut bakal membongkar nama-nama besar lain terkait korupsi KTP-el.

\subsubsection{Makna Konotatif}

Makna konotatif mengandung nilai-nilai emosi tertentu. Dalam berbahasa orang tidak haya mengungkaplan gagasan, pendapat atau isi pikiran, tetapi juga mengungkapkan emosi tertentu. Makna konotatif adalah makna berupa kiasan atau yang disertai nilai rasa, tambahntambahan sikap sosial, sikap pribadi sikap dari suatu zaman, dan kriteria-kriteria tambahan yang dikenakan pada sebuah makna konseptual. Dalam hal ini, makna disfemisme pada Media Berita Daring Kasus Setya Novanto Edisi Januari 2018 yang tergolong mengandung makna konotatif. Berikut ini dipaparkan analisis makna konotatif tersebut.

\section{TDD 5}

\section{Cabut}

(1a) Menkes Bisa Cabut Izin RS yang Rawat Setya Novanto. (B5, J5)

(2a) "Itu ranah kriminal dulu, jadi dibuktikan betul dia kriminal, kalau hukumannya dari kami cabut izin," kata Menteri Kesehatan Nila Moeloek di Jakarta, Jumat (12/1). (B5, P1K2)

Penggalan kalimat (1a) dan (2a) tersebut menunjukkan penggunaan disfemisme pada kata cabut. Kata cabut memiliki hubungan makna konotasi. Penggunaan kata cabut untuk merujuk makna mengambil hak. Secara langsung Penggunaan klausa mengambil hak ini terkesan lebih halus dan santun. Oleh karena itu, dipilih kata cabut yang dapat memberikan efek terkesan negatif sekaligus menyindir langsung dan memberi hukuman pada Rumah Sakit yang merawat Setya Novanto. Hal ini terlihat dari konteks kedua kalimat yang merujuk pada Nila Moeloek selaku Menteri Kesehatan yang Bisa Cabut Izin Rumah Sakit yang Rawat Setya Novanto bila terbukti melakukan pelanggaran tindakan kriminal.

\section{Fungsi Eufemisme dan Disfemisme Media Berita Daring Kasus Setya Novanto Edisi Januari 2018}

Bagian ini disajikan analisis makna eufemisme dan disfemisme pada media berita daring Republika Kasus Setya Novanto Edisi Januari 2018. Data-data yang telah diambil dari media berita daring tersebut telah diinventarisasi dalam bentuk tabel. Selanjutnya, analisis fungsi eufemisme dan bentuk disfemisme dipaparkan sebagai berikut.

\subsection{Fungsi Eufemisme}

Pembahasan mengenai fungsi eufemisme melibatkan pada konteks kalimat dan makna yang terdapat pada kata atau frasa dalam sebuah 
data. Fungsi eufemisme tersebut meliputi alat menghaluskan ucapan, alat merahasiakan sesuatu, alat berdiplomasi, alat pendidikan, dan alat penolak budaya, perlindungan, kecurangan, penyemangat, profokasi, kepaduan dan menggelikan. Berikut ini contoh fungsi eufemisme tersebut.

\subsubsection{Eufemisme Perlindungan Protective Eufemisme)}

Fungsi eufemisme perlindungan digunakan unutk menghindari kara yang dapat menimbulkan masalah, konflik, bahaya, emosi, kemarahan, melukai perasaan, mamalukan, menghujat, mengumpat, tabu, kata yang tidak sopan, menjijikan, dan menghindari kata yang dapat menimbulkan kepanikan. Analisis fungsi eufemisme sebagai pelindungan dalam penelitian ini sebagai berikut.

\section{TDE 1}

\section{Berandai-andai}

"KPK tidak mau berandai-andai apakah eksepsi Setya Novanto akan diterima atau tidak oleh Majelis Hakim". (B1, P2 K2)

Berdasarkan konteks tuturan pada data tersebut, penggunaan kata ulang berandai-andai digunakan sebagai eufemisme pelindungan. Hal ini terlihat pembicara menggunakan kata berandai-andai sebagai bentuk pelindungan sehingga pembicara tidak secara gamblang berasumsi terlabih dahulu secara langusng menuduh dalam hal mengiyakan eksepsi yang akan dilakukan Setya Novanto.

\subsection{Fungsi Disfemisme}

Pembahasan mengenai fungsi disfemisme sebagai kebaikan dari eufeisme yang merupakan ungkapan berkonotasi negatif. Disfemisme memiliki fungsi atau latar belakang dalam penggunaanya, seperti menyatakan hal yang tabu, tidak senonoh, menunjukkan rasa tidak suka atau tidak setuju terhadap sesuatu, penggambaran negatif terhadap sesuatu, mengungkapkan kemarahan atau kejengkelan, mengumpat atau memaki, menunjukkan rasa tidak hormat atau mernedahkan seseorang, mencela, melebihkan sesuatu, menhujat atau mengkritik, dan menunjukkan sesautu yang bernilai rendah.
Berikut ini contoh fungsi atau hal yang melatarbelakangi penggunaan disfemisme.

\subsubsection{Menunjukkan sesuatu yang bernilai rendah}

Disfemisme sebagai kebalikan dari eufemisme merupakan ungkapan yang digunakan untuk mendeskripsikan seseuatu yang bernada negatif. Disfemisme dapat berfungsi untuk menunjukkan sesuatu yang bernilai rendah sehingga dapat menimbulkan efek negatif tertentu kepada sesuatu atau pun seseorang yang mendapatkan predikat itu. Analisis fungsi disfemisme menunjukkan sesuatu bernilai rendah tentang seseorang atau sesuatu dalam penelitian ini sebagai berikut.

\section{TDD 14}

\section{Perusakan barang bukti}

"Dahnil juga menyoroti kasus dugaan perusakan barang bukti oleh dua penyidik KPK dari kepolisian yang tidak jelas hukumannya". (B10, P3K1)

Berdasarkan penggalan kalimat tersebut penggunaan disfemisme, yaitu pada kalimat perusakan barang bukti. Kalimat perusakan barang bukti berfungsi untuk menunjukkan sesuatu yang bernilai rendah sehingga dapat menimbulkan efek negatif tertentu kepada sesuatu atau pun seseorang yang mendapatkan predikat itu. Kalimat perusakan barang bukti pada konteks tersebut merujuk pada arti melakukan pelanggaran hukum. Penggunaan kalimat tersebut menggam-barkan tentang sesuatu hal yang bernilai rendah karena melanggar suatu norma dan hukum dalam masyarakat. Dalam hal ini, Danhil lah yang menyoroti kasus dugaan perusakan barang bukti oleh dua penyidik KPK dari kepolisian yang tidak jelas hukumannya tersebut.

\section{SIMPULAN DAN SARAN}

Berdasarkan hasil penelitian, terdapat 69 kata, frasa, atau klausa yang termasuk ke dalam eufemisme dan disfemisme dalam 15 berita daring Republika Perkembangan Kasus Setya Novanto Edisi Januari 2018, dapat disimpulkan beberapa hal sebagai berikut.

1. Terdapat 49 kata atau frasa yang termasuk dalam eufemisme dan 20 kata atau frasa termasuk dalam disfemisme. Eufemisme dan disfemisme dapat terbentuk melalui 
proses bentuk inovasi formal berupa pembentukan kata, modifikasi fonem, dan kata pinjaman.

2. Makna eufemisme dan disfemisme dalam 15 berita daring Republika Perkembangan Kasus Setya Novanto Edisi Januari 2018 meliputi makna kolokatif dan makna konotatif baik berupa kata, frasa, atau pun klausa.

3. Eufemisme dapat berfungsi sebagai alat perlindungan, penghalusan ucapan, provokasi, penyemangat, menutupi kecuarangan, dan berdiplomasi. Disfemisme sebagai penggambaran negatif tentang seseorang atau sesuatu hal, menunjukkan sesuatu yang bernilai rendah, melebihkan sesuatu hal, menunjukkan rasa tidak hormat.

\section{Saran}

Eufemisme dan disfemisme adalah bentuk perubahan makna dalam bahasa. Perubahan dalam bahasa mungkin terjadi dalam rangka mengakomodasi perkembangan sosial, budaya, serta teknologi di masyarakat tuturnya. Penggunaan eufemisme dan disfemisme pada media berita daring Republika Perkembangan Kasus Setya Novanto memilik proses, makna, dan fungsi tertentu. Melalui hasil penelitian ini, diharapkan kepada pembaca dan pengguna media daring, dapat mencerna informasi yang disampaikan dengan penggunaan eufemisme dan disfemisme di dalamnya

\section{DAFTAR RUJUKAN}

Allan, Keith dan Kate Burridge. 2006. Forbidden Words, Taboo and the Consoring of Language. New York: Cambridge University Press.

Astuti, Yuli Amelia. 2016. "Eufemisme Bahasa Pendukung Capres RI Tahun 2014 dalam Akun Facebook: Kajian Sosiopragmatik". Tesis pada Program Studi Linguistik. Universitas Andalas.
Chaer, Abdul. 2009. Pengantar Semantik Bahasa Indonesia.Jakarta: Rineka Cipta.

Djajasudarma. 1993. Semantik Pemahaman Ilmu Makna. Bandung: PT. Eresco.

Keraf, Gorys. 1996. Diksi dan Gaya Bahasa. Jakarta: Gramedia Pustaka Utama.

Kurniawati, 2009. "Eufemisme dan Disfemisme dalam Spiegel Online" Tesis pada Program Magister Linguistik Universitas Negeri Yogyakarta.

Leech, Geoffrey. 1981. Semantics: The Study of Meaning. New York: Penguin Books.

Mahsun. 2012. Metode Penelitian Bahasa Tahapan Strategi, Metode, dan Tekniknya. Jakarta: Rajawali Pers.

McArthur. 1992. The Oxford Companion to the English Language.Oxford: Oxford University Press.

Palmer, Robert. 1976. Semantics $2^{\text {nd }}$ Edition. Cambridge University Press.

Pateda, Mansoer. 2001. Semantik Leksikal. Jakarta: Rineka Cipta.

Pinker, Steven. 1994. The Language Instict. NewYork: A Division of Harper Collins Publisher.

Rababah, H. A. 2014. The Translatability and use of X-Phemism Expressions (XPhemization): Euphemisms, Dyphemisms and Orthophemisms In the Medical Discourse. Studies in Literature and Language, Vol 9, No 3, Hlm. 229-240

Warren, Beatrice. 1992. What Euphemism Tell Us about the Interpretation of Words. Studia Linguistica.

Wijana, IPutu Dewa. 2008. Semantik: Teori dan Analisis. Surakarta: Yuma Pustaka.

Sudaryanto. 2015. Metode Aneka Teknik Analisis Data.Yogyakarta: Duta Wacana University Press. 